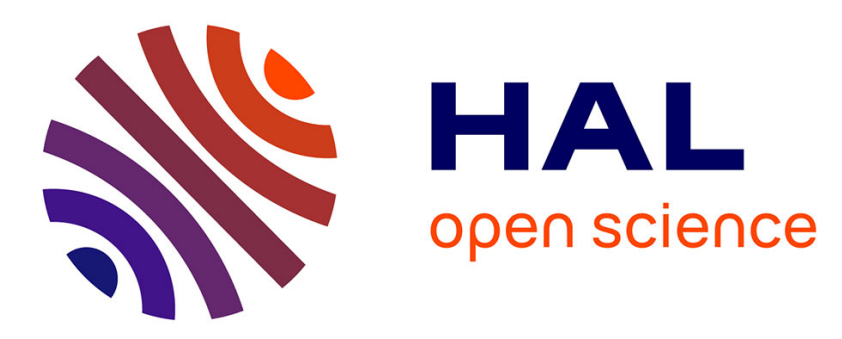

\title{
Fluorescein diacetate hydrolysis as a measure of microbial activity in aquatic systems: Application to activated sludges
}

\author{
D. A. Fontvieille, A. Outaguerouine, Daniel R. Thevenot
}

\section{To cite this version:}

D. A. Fontvieille, A. Outaguerouine, Daniel R. Thevenot. Fluorescein diacetate hydrolysis as a measure of microbial activity in aquatic systems: Application to activated sludges. Environmental Technology, 1992, 13 (6), pp.531-540. hal-01179839

\section{HAL Id: hal-01179839 \\ https://hal.science/hal-01179839}

Submitted on 23 Jul 2015

HAL is a multi-disciplinary open access archive for the deposit and dissemination of scientific research documents, whether they are published or not. The documents may come from teaching and research institutions in France or abroad, or from public or private research centers.
L'archive ouverte pluridisciplinaire HAL, est destinée au dépôt et à la diffusion de documents scientifiques de niveau recherche, publiés ou non, émanant des établissements d'enseignement et de recherche français ou étrangers, des laboratoires publics ou privés. 


\title{
FLUORESCEIN DIACETATE HYDROLYSIS AS A MEASURE OF MICROBIAL ACTIVITY IN AQUATIC SYSTEMS: APPLICATION TO ACTIVATED SLUDGES
}

\author{
D.A. Fontvieille ${ }^{1 *}$, A. Outaguerouine ${ }^{2}$ And D.R. Thevenot ${ }^{3}$ \\ ${ }^{1}$ Laboratoire d'Ecologie, Université de Savoie, BP 1104, 73011 Chambéry Cedex, France and UA CNRS \\ 367, 43 bd du 11 nov. 1918, Université Claude Bernard, 69622 Villeurbanne, France \\ ${ }^{2}$ Laboratoire de Bioélectrochimie et Analyse du Milieu (L.A.B.A.M.), U.F.R. de Sciences et de \\ Technologie, Université Paris-Val de Marne, 94010 Créteil Cedex, France \\ ${ }^{3}$ C.E.M.A.G.R.E.F., Unité Qualité des Eaux Pêche et Pisciculture, 14 avenue de Saint-Mandé \\ 75012 Paris Cedex, France
}

(Received 27 August 1990; Accepted 28 February 1991)

\begin{abstract}
Fluorescein diacetate (FDA) hydrolysis has mainly been used, in soil stydies, for measurement of microbial activity and/or for enumeration of bacteria. A protocol is proposed to apply the method to sewage treatment plant activated sludge. The results are compared with values of ETS (electron transport system) activity and oxygen consumption. Unlike ETS activity, FDA hydrolysis is not expected to be proportional to $\mathrm{O}_{2}$ consumption. However, its application to aquatic systems is simpler, less expensive and give results with better reproducibility. FDA hydrolysis may thus allow study of biological activity in situations where extensive surveys in time and/or space are needed.
\end{abstract}

Keywords: Fluorescein diacetate, FDA, hydrolysis, electron transport system, ETS, INT, microbial activity, oxygen consumption, activated sludge, waste water treatment plant.

\section{INTRODUCTION}

Aquatic systems descriptions are commonly based on physical and chemical parameters of water and/or sediments. Biological components are less often considered and usually assessed through composition and abundance of populations like fishes, algae or macroinvertebrates. A third approach for the general survey of aquatic systems is represented by measurements of metabolic activity of microbial populations either in water or in sediments. One of the most interesting features of these measures is that they describe with a single value, both presence and physiological activity of organisms. The results thus integrate past and present environmental conditions to which biocenoses are subjected (1).
Experiments described in this paper are parts of a program, dealing with methods (mainly enzymatic methods) leading to integrative indices of microbial metabolic rates in nature and industrial processes. One of the most widely used, among enzymatic methods for microbial activity assessment, is the ETS activity (Electron Transport System activity), based on reduction of INT (2-(p-iodophenyl)-3-(p-nitrophenyl)-5phenyl tetrazolium chloride), a tetrazolium salt. This measure involves reactions that agree with most of the expected properties for such methods:

- sites where reactions occur along metabolic pathways are, in most cases, well known (2);

- as a consequence of their connection with the electron transport system, the reactions are correlated with the respiration rate $(3,4)$, even under anaerobic conditions. 
However, the INT protocol presents at least three disadvantages that justify a search for alternative methods:

- it measures a potential activity because the protocol includes an addition of pyridinic nucleotides and of $\mathrm{KCN}$ to poison further electron transfer beyond the point where INT is reduced.

- some of the chemicals used, such as nicotinamide adenine dinucleotide (NADPH), are expensive; other such as $\mathrm{KCN}$ are very toxic.

- it needs several solutions to prepare before the incubation, two of them bearing only short term storage.

Hydrolysis of fluorescein diacetate (FDA) was first applied to environmental studies for enumeration of procaryotic and eucaryotic microorganisms in soil $(5,6)$. It has also been used to study microbial metabolic activity in soil $(7,8)$. The method is based on the ability of several enzymes (e.g. esterases, lipases, proteases), produced by bacteria or fungi, to split the FDA molecule, thereby producing fluorescein which can be measured spectrophotometrically or fluorometrically.

This study presents a protocol for the measure of FDA activity in aquatic systems as represented by biological reactors of sewage treatment plants. A comparison is made with ETS activity and $\mathrm{O}_{2}$ consumption.

\section{MATERIAL AND METHODS}

As one of the main topics this work was dealing with, detailed protocol of the measure of FDA activity is presented below together with the other results of the study.

All experiments were conducted on microbial populations of activated sludge sampled in completely mixed aeration tanks from a pilot (receiving discontinuous $\mathrm{O}_{2}$ supply and fed with "Viandox", a commercial meat extract solution) or from industrial treatment plants in the vicinity of Paris. FDA activity was measured together with $\mathrm{O}_{2}$ consumption and ETS activity.

ETS activity was measured according to the protocol proposed by PACKARD (9), except for the two following points:

- instead of filtering the bacterial suspension and determining ETS activity directly on the filter, we ground in a potter glass grinder, a mixture of $1 \mathrm{ml}$ activated sludge, $5 \mathrm{ml}$ homogenization buffer and a $47 \mathrm{~mm}$ Whatman
GF/F glass fibre filter. The filter was used only to make the grinding more efficient. Activated sludges were sampled with a $5 \mathrm{ml}$ syringe. The $0.1 \mathrm{M}$ phosphate homogenization buffer contained also $0.2 \%(\mathrm{v} / \mathrm{v})$ Triton X100, $2 \mathrm{~g} \mathrm{l}^{-1}$ polyvinyl pyrrolidone, $18 \mathrm{mg} \mathrm{l}^{-1} \mathrm{MgSO}_{4}$ and $325 \mathrm{mg} \mathrm{l}^{-1} \mathrm{KCN}$;

- after the reaction was stopped by the addition of a mixture of $0.3 \mathrm{M}$ orthophosphoric acid and $4 \%$ $\mathrm{v} / \mathrm{v}$ formaldehyde, the sample was centrifuged $(2000 \mathrm{G})$ and the supernatant analyzed by spectrophotometry.

INT was obtained from Merck, NADH (grade I) and NADPH (grade I) from Boehringer and all other reagents from Prolabo (Normapur reagent grade).

Oxygen consumption was calculated from records of $\mathrm{O}_{2}$ concentration made on sealed samples previously aerated for 2 hours. At this time $\mathrm{O}_{2}$ consumption was always constant and was assumed to represent endogenous respiration, although no verification was made that external growth substrates were absent. The results are expressed in milligrams $\mathrm{O}_{2}$ consumed per hour and per gram volatile suspended solids (VSS) (or per litre sludge sample) at a standard temperature of $25^{\circ} \mathrm{C}$.

Other measurements performed during these experiments to characterize the evolution of the activated sludges included: $\mathrm{pH}, \mathrm{O}_{2}$ concentration, dry weight of suspended solids (SS), and volatile suspended solids measured by ignition at $550^{\circ} \mathrm{C}$ (VSS).

\section{RESULTS}

Measure of FDA Activity.

The protocol described in Figure 1 has been tested on pilot plants at the C.E.M.A.G.R.E.F.

laboratory (Paris) and on two industrial sewage treatment plants in the vicinity of Paris: Fontenay-Tresigny (Seine-et-Marne) and Colombes (Hauts-de-Seine).

Two millilitres of activated sludge were diluted with $10 \mathrm{ml}$ of a $0.1 \mathrm{M}$ phosphate buffer (PBS) ( $\mathrm{pH}$ 7.6) and vortexed for about 15 sec. The measure was generally performed simultaneously on six replicates, each consisting of $4 \mathrm{ml}$ PBS (previously cooled by immersion in an ice-cold water bath), of $1 \mathrm{ml}$ of the diluted sample and of $0.1 \mathrm{ml}$ of a $4.8 \mathrm{mM}$ FDA (Aldrich) solution. Two blanks were used (Fig. 1), one for the control of the FDA autohydrolysis (T1) and one for the determination of a possible natural coloration of the sample (T2). The incubation was performed in a water bath at $20^{\circ} \mathrm{C}$. 


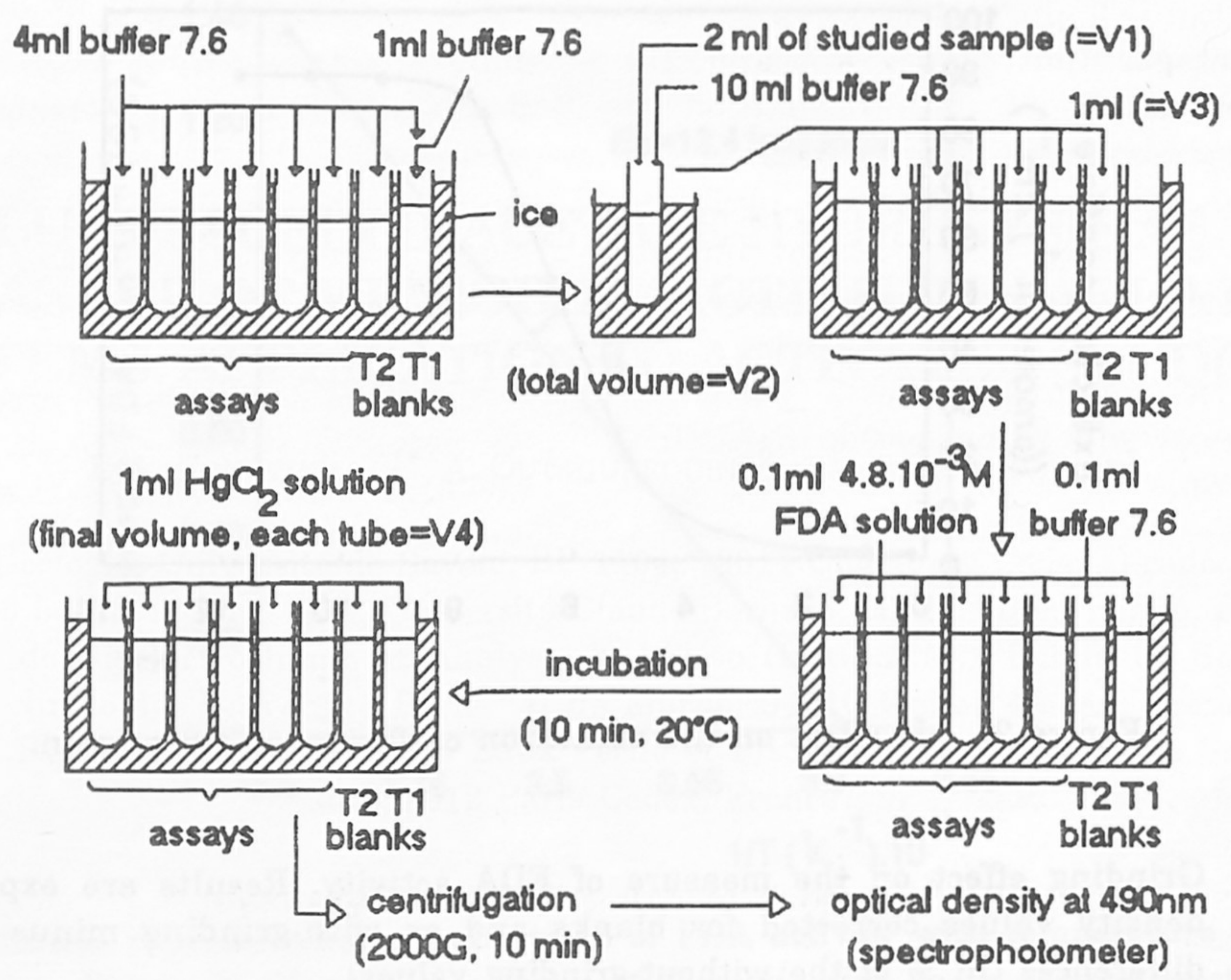

Figure 1. Protocol for the measurement of FDA activity in activated sludge.

It was stopped after $10 \mathrm{~min}$ by addition of $1 \mathrm{ml}$ of a $400 \mathrm{mg} \mathrm{l}^{-1} \mathrm{HgCl}_{2}$ solution. Each tube was then centrifuged $\left(10 \mathrm{~min}, 2000 \mathrm{G}, 4^{\circ} \mathrm{C}\right)$. The optical density of the supernatant was measured at 490 $\mathrm{nm}$. One of the purposes of the study being to propose as simple a method as possible, with reduced requirement of time and equipment, the spectrophotometric measure of fluorescein was preferred to a measure by fluorimetry.

The final expression of FDA activity is given as the number of micromoles of FDA hydrolysed per minute and per gram of VSS according to the following expression:

$$
\begin{aligned}
& \text { Hydrolytic activity }\left(\mu \mathrm{mol} \mathrm{min}^{-1} \mathrm{~g}^{-1} \mathrm{VSS}\right) \\
& =\frac{\mathrm{OD}}{81.5} \times \frac{1}{\mathrm{t}} \times \mathrm{V} 4 \times \frac{\mathrm{V} 2}{\mathrm{~V} 3} \times \frac{1}{\mathrm{~V} 1} \times \frac{1}{\mathrm{C}}
\end{aligned}
$$

where OD $\left(\mathrm{cm}^{-1}\right)$ is the optical density at $490 \mathrm{~nm}$ corrected for blanks ( $\mathrm{T} 1$ and $\mathrm{T} 2$ ); $\mathrm{t}(\mathrm{min})$ is the incubation time; volumes V1, V2, V3, and V4 (ml) are those volumes referred to in Figure 1; 81.5 is the extinction coefficient of fluorescein ( $\mu \mathrm{mol} \mathrm{ml} \mathrm{m}^{-1} \mathrm{~cm}^{-1}$ ) at $\mathrm{pH} 7.6$ and $\mathrm{C}\left(\mathrm{g} \mathrm{ml}^{-1}\right)$ is the VSS concentration of the sample.

One of the main difficulties of the spectrophotometric measurement of fluorescein is related to its $\mathrm{pH}$-dependent extinction coefficient (Fig. 2). From the necessity of performing incubations at a $\mathrm{pH}$ close to that of activated sludges, the value chosen for the $\mathrm{pH}$ of the dilution buffer was 7.6. This value appeared to be convenient in most cases, even though, near this $\mathrm{pH}$, the extinction coefficient is still $\mathrm{pH}$ -dependent.

Two experiments, each with four assays, were performed to determine whether it was necessary to start the analysis by grinding the samples, as in the INT protocol. The samples tested in these experiments were ground together with $47 \mathrm{~mm}$ diameter glass fibre filters using a Potter cell grinder. The values reported in Table 1 show that the resulting increase of activity was below $10 \%$ in both experiments. This step was therefore omitted in the last version of the protocol.

Like all enzymatic reactions, hydrolysis of FDA is time- and temperature-dependent. It was thus necessary to study the kinetics of the reaction at different temperatures, to determine what concentration of FDA was necessary so as the rate of hydrolysis would not be limited by FDA. Figure 3 shows that the reaction rate is constant, at all temperatures, during the first 10 min of incubation for the quantity of FDA used in the protocol: the $\mathrm{Q}_{10}$ of the reaction equals 1.96 (standard error of the mean $=0.13$ ). Using the Arrhenius representation of FDA hydrolysis versus temperature, (Fig. 4), the activation energy was found to be $13.4 \mathrm{kcal} \mathrm{mol}^{-1}$. 


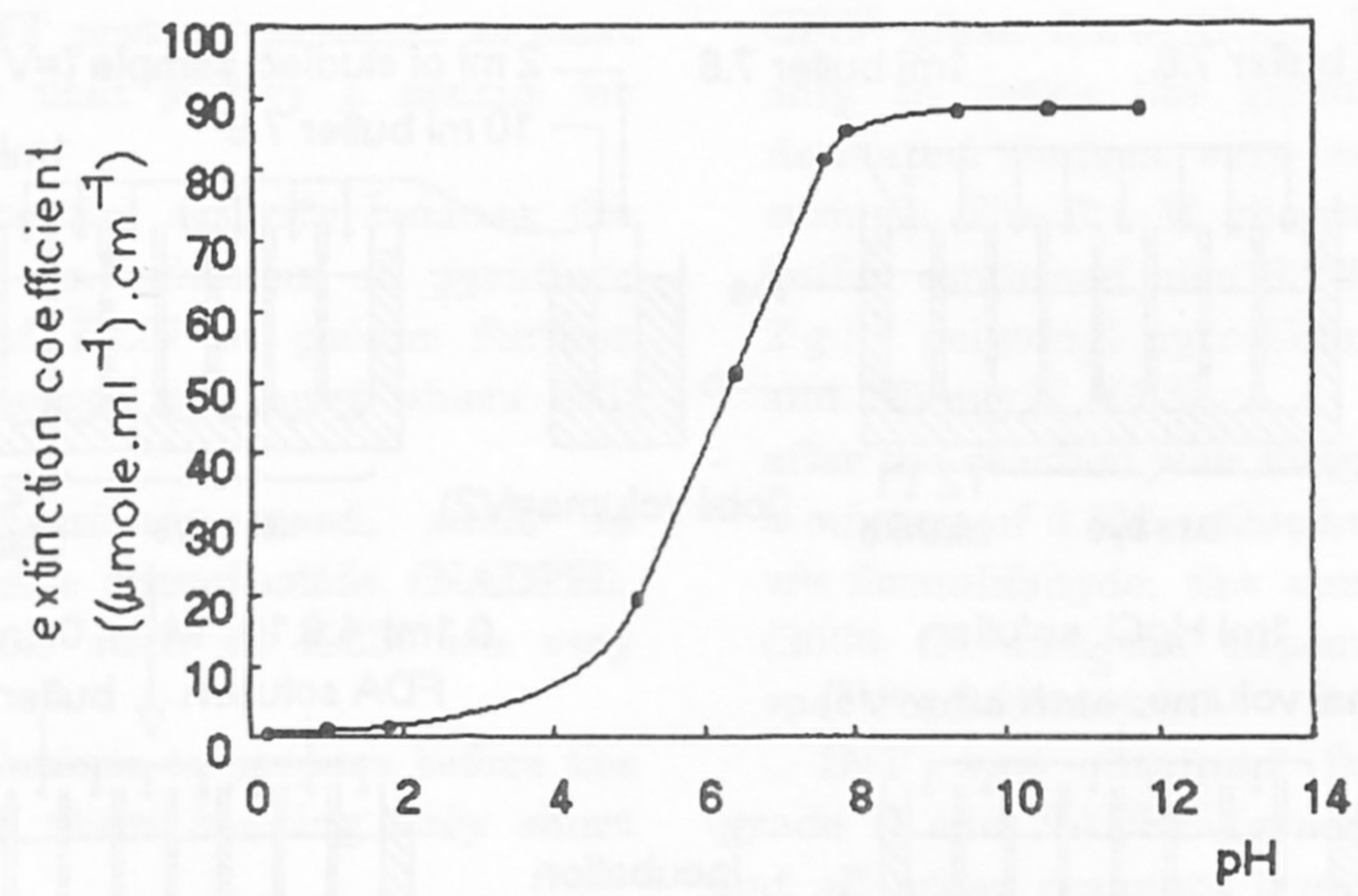

Figure 2. $\mathrm{pH}$ effect on the extinction coefficient of fluorescein.

Table 1. Grinding effect on the measure of FDA activity. Results are expressed as optical density values corrected for blanks and as with-grinding minus without-grinding differences (in \% of the without-grinding values).

\begin{tabular}{|c|c|c|c|c|}
\hline \multirow[b]{2}{*}{ Assays } & \multicolumn{2}{|c|}{ experiment 1} & \multicolumn{2}{|c|}{ experiment 2} \\
\hline & $\begin{array}{l}\text { without } \\
\text { grinding }\end{array}$ & $\begin{array}{c}\text { with } \\
\text { grinding } \\
\end{array}$ & $\begin{array}{l}\text { without } \\
\text { grinding }\end{array}$ & $\begin{array}{c}\text { with } \\
\text { grinding }\end{array}$ \\
\hline 1 & 0.075 & 0.079 & 0.112 & 0.128 \\
\hline 2 & 0.082 & 0.084 & 0.114 & 0.123 \\
\hline 3 & 0.076 & 0.082 & 0.116 & 0.121 \\
\hline 4 & 0.084 & 0.083 & 0.116 & 0.122 \\
\hline mean & 0.079 & 0.083 & 0.114 & 0.123 \\
\hline differences (\%) & \multicolumn{2}{|c|}{5.06} & \multicolumn{2}{|c|}{7.89} \\
\hline mean difference $(\%)$ & & & & \\
\hline
\end{tabular}

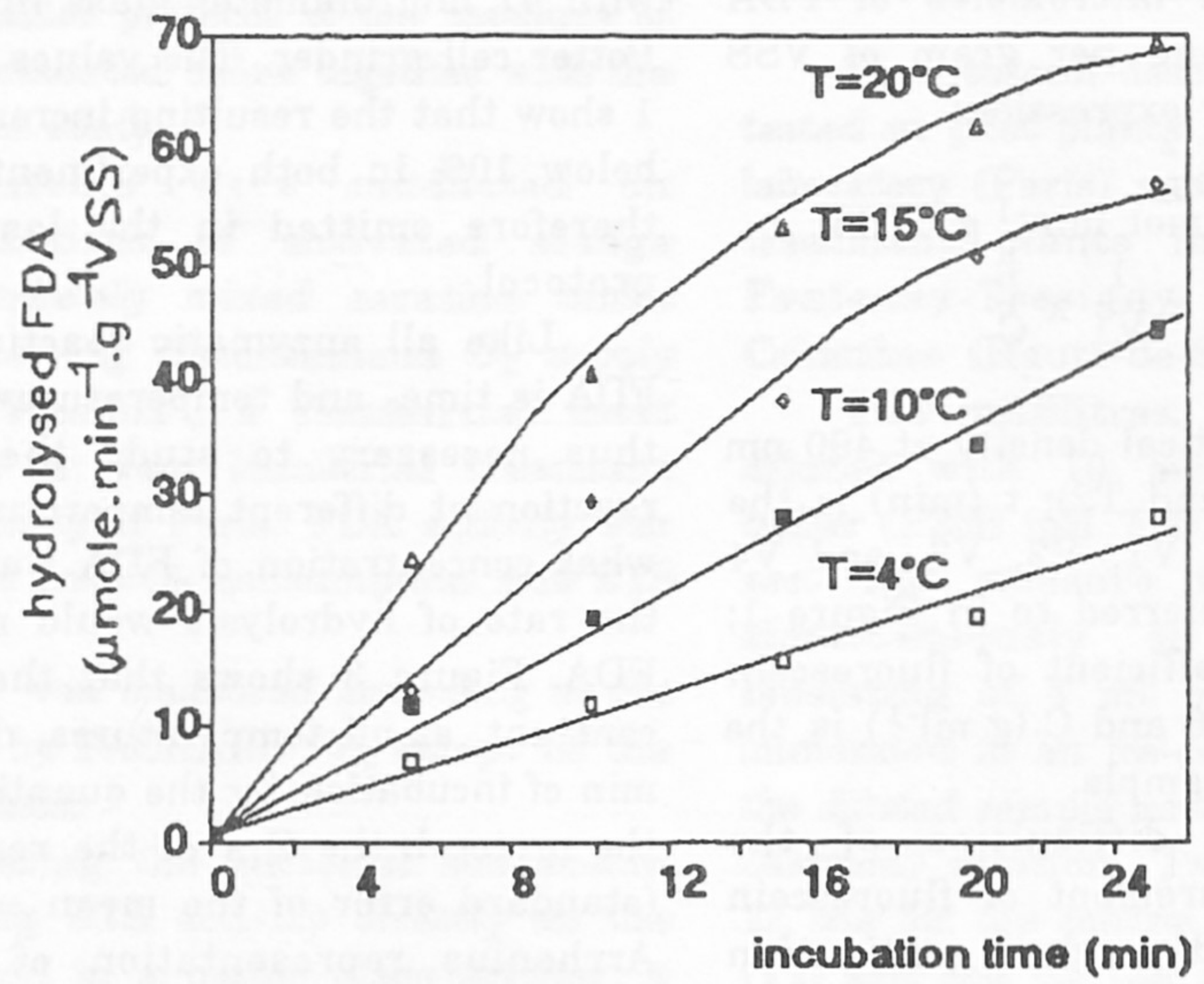

Figure 3. Effect of incubation temperature on FDA hydrolysis kinetic. Measures performed on sludge from a pilot treatment plant. 


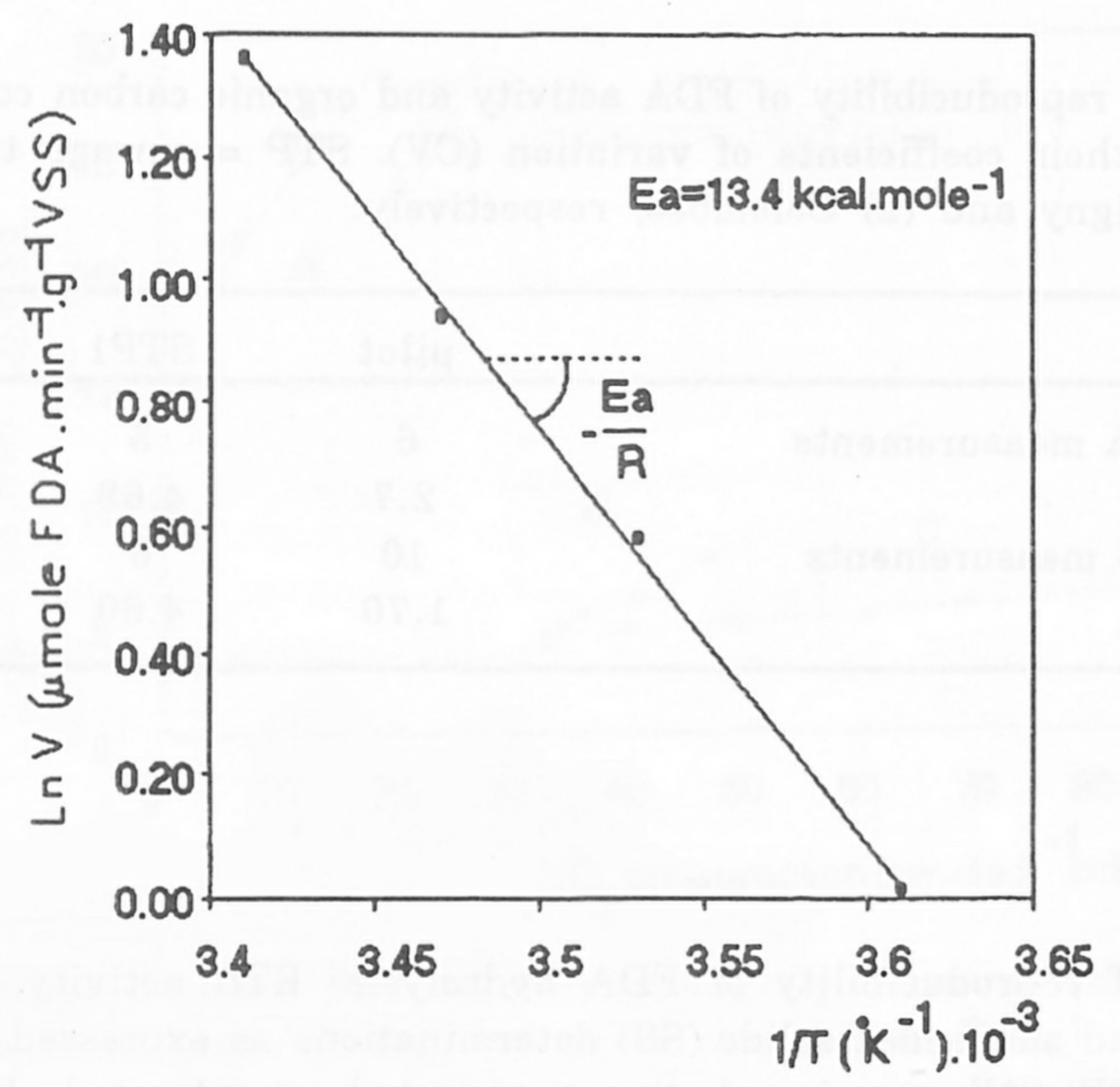

Figure 4. Arrhenius representation of variations of FDA activity with temperature (same results as used in Figure 3) allowing calculation of the activation energy of the reaction between $4^{\circ} \mathrm{C}$ and $20^{\circ} \mathrm{C}$.

Comparison between FDA and ETS activities

When considered for medium to large periods (daily averages, for example) and when a steady state was established for sludges, nutrients input and oxygen supply, the correlation between ETS and FDA activities was always highly significant ( $\mathrm{r}^{2}$ above 0.87 , with $\alpha=$ 0.01; OUTAGUEROUINE, 10).

From our results the values of both, $Q_{10}$ and activation energy, calculated for ETS and FDA activities, were very similar (Table 2). However, ETS activity appeared slightly less affected by variations of temperature than FDA activity. The value found in our experiments for ETS activation energy was very close to those reported by PACKARD et al. (11), i.e. $13.8 \mathrm{kcal}$ $\mathrm{mol}^{-1}$ and KENNER et al. (13), i.e., $15.8 \mathrm{kcal}$ $\mathrm{mol}^{-1}$, for marine plankton.
Reproducibilities of ETS and FDA activities have been compared with each other by reference to standard deviations of suspended solids (SS) and volatile suspended solids (VSS) concentrations. Data used for these calculations were achieved from activated sludges of a laboratory pilot plant and of two industrial sewage treatment plants. Values reported in Table 3 show that:

- Variability of FDA activity was less for sludge sampled from the pilot plant than for sludge sampled from industrial plants, as expected from the greater homogeneity of the pilot.

- Variability of FDA activity was very close to, and followed, variability of VSS.

Furthermore Table 4 shows that reproducibility was slightly better for FDA activity than for ETS activity when considering results achieved from the pilot plant.

Table 2. Comparison of $Q_{10}$ and activation energy of ETS and FDA activities. All measures performed on activated sludges from a laboratory pilot plant.

\begin{tabular}{ccccc}
\hline & $\mathrm{Q}_{10}$ & & \multicolumn{2}{c}{ activation energy $\left(\mathrm{kcal} \mathrm{mol}^{-1}\right)$} \\
\hline ETS & FDA & ETS & FDA \\
$2.19 \pm 0.13$ & & $1.96 \pm 0.13$ & 14.2 & 13.4 \\
\hline
\end{tabular}


Table 3. Comparison of reproducibility of FDA activity and organic carbon concentration (VSS), as measured by their coefficients of variation (CV). STP = sewage treatment plant in (l) Fontenay-Tresigny and (2) Colombes, respectively.

\begin{tabular}{lccc}
\hline & pilot & STP1 & STP2 \\
\hline Number of FDA measurements & 6 & 5 & 6 \\
CV $(\%)$ & 2.7 & 4.63 & 4.93 \\
Number of VSS measurements & 10 & 6 & 6 \\
CV $(\%)$ & 1.70 & 4.60 & 4.72 \\
\hline
\end{tabular}

Table 4. Comparison of reproducibility of FDA hydrolysis, ETS activity, volatile suspended solids (VSS) and suspended solids (SS) determinations as expressed by their coefficients of variation (CV). All experiments were conducted on activated sludges sampled in a pilot treatment plant.

\begin{tabular}{lcccc}
\hline & SS $\left(\mathrm{g} \mathrm{l}^{-1}\right)$ & VSS $\left(\mathrm{g} \mathrm{l}^{-1}\right)$ & $\begin{array}{c}\text { FDA activity }(\mu \mathrm{mol} \\
\left.\text { min }^{-1} \mathrm{~g} \mathrm{VSS}^{-1}\right)\end{array}$ & $\begin{array}{c}\text { ETS activity }(\mu \mathrm{mol} \\
\left.\text { min }^{-1} \mathrm{~g} \mathrm{VSS}^{-1}\right)\end{array}$ \\
\hline No. of measurement & 10 & 10 & 16 & 16 \\
Mean value & 13.15 & 10.46 & 28 & 55 \\
CV $(\%)$ & 1.6 & 1.6 & 2.8 & 4.9 \\
\hline
\end{tabular}

Comparison between FDA Activity and $\mathrm{O}_{2}$ Consumption

Figure 5 presents linear regressions calculated from measures of FDA activity and $\mathrm{O}_{2}$ consumption performed on activated sludges from laboratory pilot plants and industrial sewage treatment plants. These measures thus represent a wide range of temperature (13 to $20^{\circ} \mathrm{C}$ ), aeration rates and trophic supplies.

Sludge A, in particular, comes from an endogenous phase of a pilot plant. Sludges B and $\mathrm{C}$, but not $\mathrm{A}$, show a highly significant correlation between the two measures of microbial activity. Only the slopes of the regression lines vary from one experiment to the other and then can be assumed to represent differences in activated sludges composition and/or effects of different environmental conditions. Next steps in these experiments should try to relate these slope variations to the main specific events that can affect activated sludge.

An experiment has been designed to compare FDA hydrolysis and $\mathrm{O}_{2}$ consumption in their ability to differentiate the effects of temperature on activated sludge metabolism. During this experiment two pilots were run simultaneously, one at $13^{\circ} \mathrm{C}$ (cold pilot), the second at $26^{\circ} \mathrm{C}$ (warm pilot). For each of them, microbial activities (FDA activity and $\mathrm{O}_{2}$ consumption) were followed on samples isolated from the main tank, during at least 4 hours, at both their original temperatures and the temperature of the other pilot. Results are reported in Figure 6 and Table 5. For both pilots, metabolic rates change quickly (within an hour) after the running temperature was modified. Table $5 \mathrm{~B}$ shows that $\mathrm{O}_{2}$ consumption better described the effects of temperature either on initial metabolic activity of the pilots (Table 5, col. 2) or on further changes of metabolic rates that occur during the following 4 hours of incubation (Table 5, col. 3, 4, 5). Hydrolytic activity would thus be less sensitive than $\mathrm{O}_{2}$ consumption to rapid changes of temperature in waste water treatment plants. 


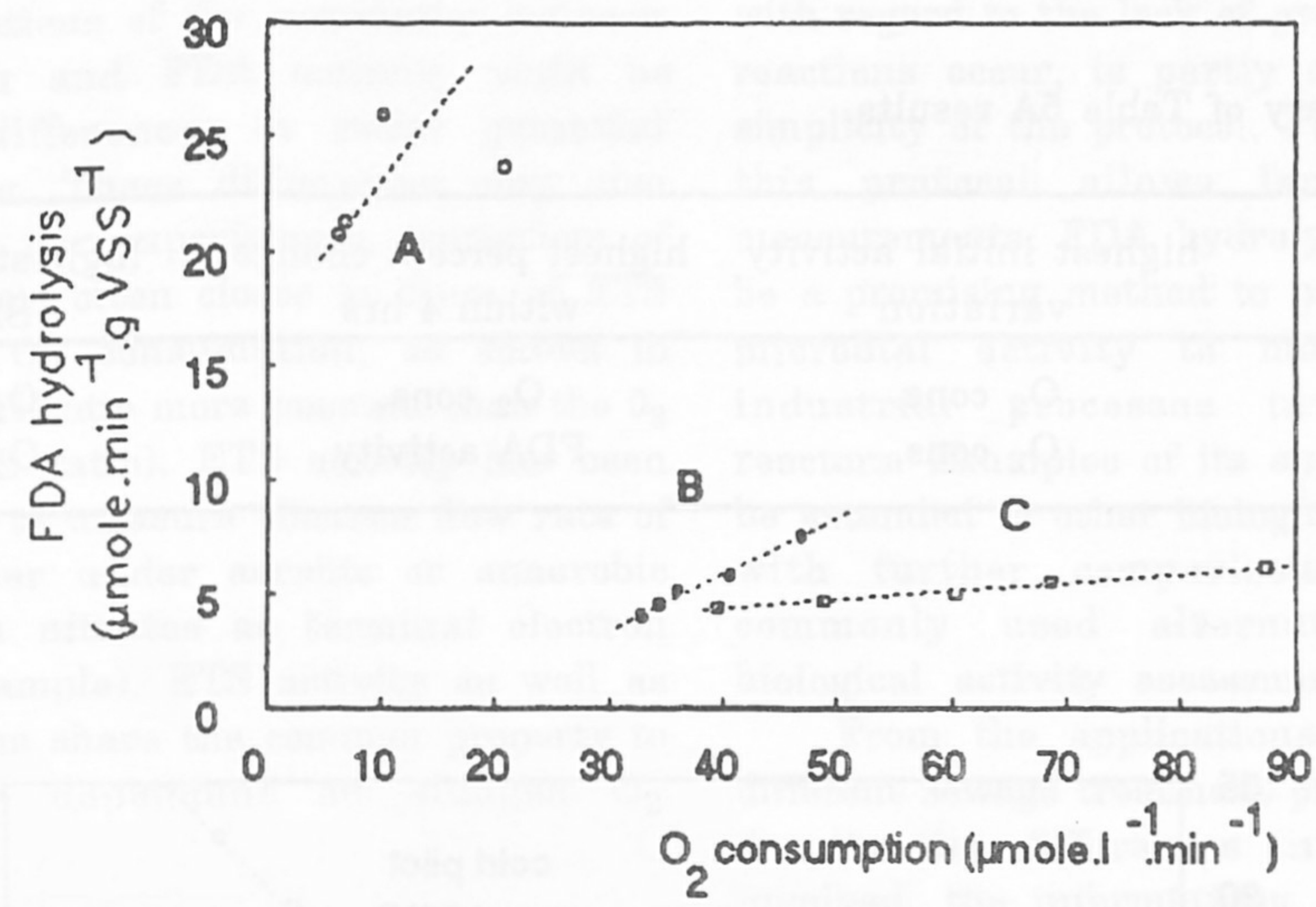

Figure 5. Relationships between FDA hydrolysis and $\mathrm{O}_{2}$ consumption. A : sludge sample from a pilot treatment plant during endogenic respiration. B : sludge sample from Fontenay Tresigny sewage treatment plant. C : sludge sample from a pilot treatment plant with regular trophic supply.

Table 5A. Effect of running temperature on activities of sludge samples isolated from two pilot plants (one "cold", incubated at $13^{\circ} \mathrm{C}$, one "warm", incubated at $26^{\circ} \mathrm{C}$ ).

\begin{tabular}{|c|c|c|c|c|c|c|}
\hline & & $\begin{array}{l}\text { runn. } \\
\text { temp. }\end{array}$ & $\begin{array}{c}\text { initial } \\
\text { activity } \\
\text { variation } \\
(\%) \\
\end{array}$ & $\begin{array}{c}\text { relative } \\
\text { variation } \\
\text { within the } 4 \mathrm{hrs} \\
\text { incubation }(\%)\end{array}$ & $\begin{array}{c}\text { absolute variation } \\
\text { within the } 4 \mathrm{hrs} \\
\text { incubation } \\
\text { (slope) }\end{array}$ & $\begin{array}{l}\text { column } 4 \\
\text { slopes ratios } \\
(\mathrm{S} 26 / \mathrm{S} 13)\end{array}$ \\
\hline colum & $n \#$ & 1 & 2 & 3 & 4 & 5 \\
\hline \multirow{2}{*}{$\begin{array}{l}\text { warm } \\
\text { pilot }\end{array}$} & $\begin{array}{c}\text { FDA } \\
\text { activity }\end{array}$ & $\begin{array}{l}13 \\
26\end{array}$ & -63.5 & $\begin{array}{l}15.5 \\
10.7\end{array}$ & $\begin{array}{l}0.28 \\
0.52\end{array}$ & 1.9 \\
\hline & $\begin{array}{c}\mathrm{O}_{2} \\
\text { consum. }\end{array}$ & $\begin{array}{l}13 \\
26 \\
\end{array}$ & -64.8 & $\begin{array}{l}19.4 \\
16.4 \\
\end{array}$ & $\begin{array}{l}0.28 \\
0.68\end{array}$ & 2.4 \\
\hline \multirow{2}{*}{$\begin{array}{l}\text { cold } \\
\text { pilot }\end{array}$} & $\begin{array}{c}\text { FDA } \\
\text { activity }\end{array}$ & $\begin{array}{l}13 \\
26 \\
\end{array}$ & +179.2 & $\begin{array}{l}21.9 \\
16.3 \\
\end{array}$ & $\begin{array}{l}0.64 \\
1.33 \\
\end{array}$ & 2.1 \\
\hline & $\begin{array}{c}\mathrm{O}_{2} \\
\text { consum. }\end{array}$ & $\begin{array}{l}13 \\
26\end{array}$ & +204 & $\begin{array}{l}10.7 \\
14.3\end{array}$ & $\begin{array}{l}0.13 \\
0.53\end{array}$ & 4.1 \\
\hline
\end{tabular}

Calculations are based on metabolic rate decrease (consequent to the nutrient depletion) during the first 4 hours of the measurements. Units are $\mu \mathrm{mol} \mathrm{O}_{2} \mathrm{~min}^{-1} \mathrm{~g} \mathrm{VSS}^{-1} \mathrm{O}_{2}$ consumption, and $\mu \mathrm{mol} \mathrm{FDA} \mathrm{min}^{-1} \mathrm{~g} \mathrm{VSS}^{-1}$ for hydrolytic activity:

col. 2 (cold pilot) $=\frac{\left[\mathrm{A}^{0}{ }_{26}-\mathrm{A}^{0}{ }_{13}\right] \times 100}{\mathrm{~A}^{0}{ }_{13}}$

(denominator changed to $\mathrm{A}^{0}{ }_{26}$ for column 2, warm pilot)

$\mathrm{A}^{0}{ }_{26}=$ activity at time 0 and $26^{\circ} \mathrm{C} ; \mathrm{A}^{0}{ }_{13}=$ activity at time 0 and $13^{\circ} \mathrm{C}$;

col. $3=\frac{\left[\text { activity at time } 0-\text { activity at time } t_{0}+4 \mathrm{hrs}\right] \times 100}{\text { activity at time } 0} ;$

col. $4=\frac{\text { activity at time } 0-\text { activity at time } t_{0}+4 \mathrm{hrs}}{4}$;

col. $5=\frac{\text { slope at } 26^{\circ} \mathrm{C}}{\text { slope at } 13^{\circ} \mathrm{C}}$. 
Table 5B. Summary of Table 5A results.

\begin{tabular}{lccc}
\hline & $\begin{array}{c}\text { highest initial activity } \\
\text { variation }\end{array}$ & $\begin{array}{c}\text { highest percent change } \\
\text { within } 4 \text { hrs }\end{array}$ & $\begin{array}{c}\text { highest slope ratio } \\
\mathrm{S} 26 / \mathrm{S} 13\end{array}$ \\
\hline $\begin{array}{l}\text { warm pilot } \\
\text { cold pilot }\end{array}$ & $\mathrm{O}_{2}$ cons. & $\mathrm{O}_{2}$ cons. & $\mathrm{O}_{2}$ cons. \\
& $\mathrm{O}_{2}$ cons. & FDA activity & $\mathrm{O}_{2}$ cons. \\
\hline
\end{tabular}

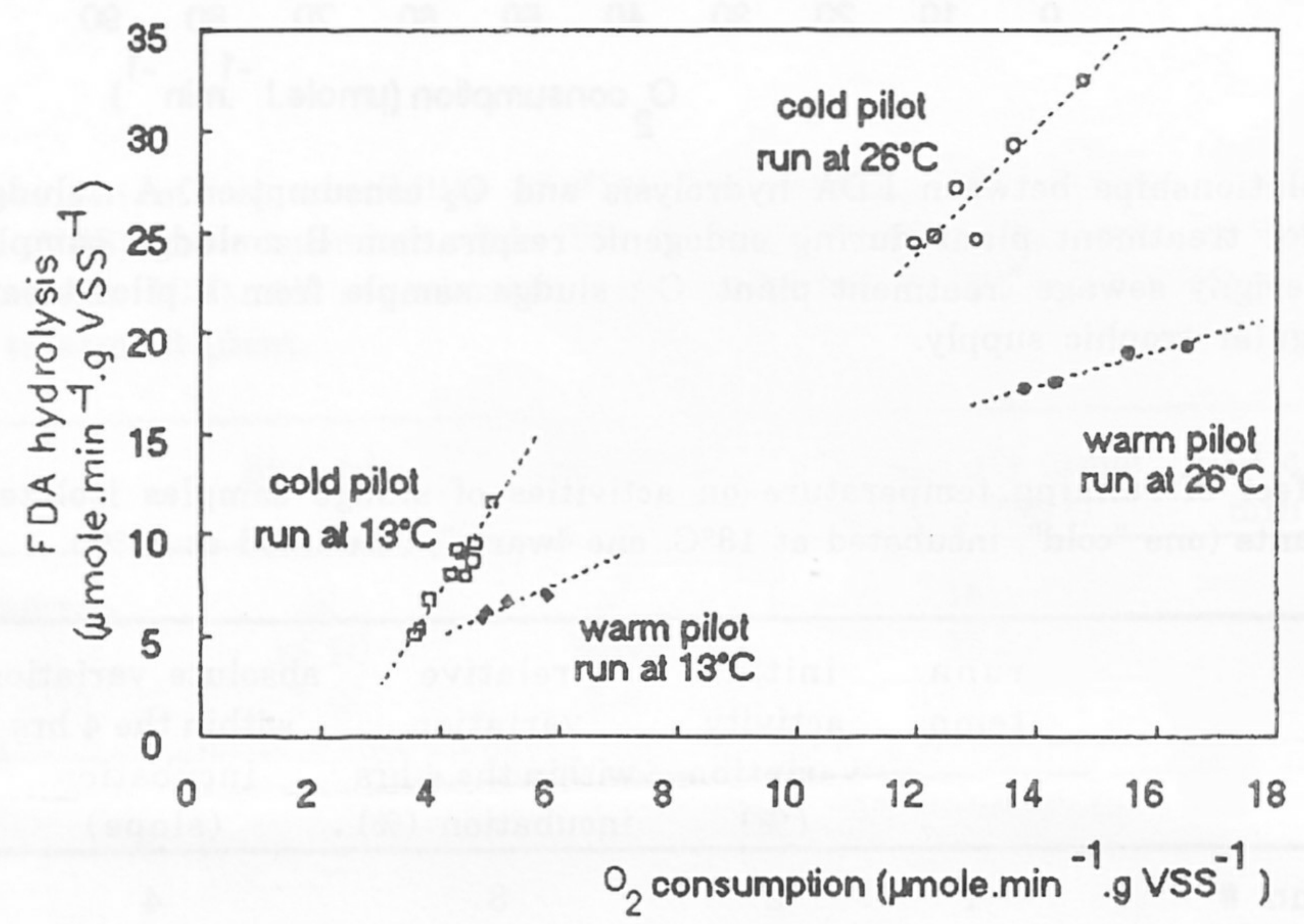

Figure 6. Temperature effect on sludge activity of two pilot treatment plants. See text for explanations. In each case activities were followed during at least 4 hours (one measure every $30 \mathrm{~min}$ ) on sludge samples isolated from the main tank. First measurement of each data set always gave the highest value for both FDA and $\mathrm{O}_{2}$ consumption.

Table 6. Comparison of FDA activity and $\mathrm{O}_{2}$ consumption normalized to ETS activity. Both experiments done on sludge samples isolated from two laboratory pilot plants with different rates of food supply.

\begin{tabular}{|c|c|c|c|c|c|}
\hline time $(\min )$ & $\begin{array}{c}\text { experiment } 1 \\
\text { FDA/ETS } \\
\end{array}$ & $\mathrm{O}_{2}$ cons./ETS & time $(\min )$ & $\begin{array}{c}\text { experiment } 2 \\
\text { FDA/ETS }\end{array}$ & $\mathrm{O}_{2}$ cons./ETS \\
\hline 0 & 0.75 & 0.35 & 0 & 0.34 & 0.14 \\
\hline 60 & 0.76 & 0.31 & 30 & 0.37 & 0.14 \\
\hline 120 & 0.69 & 0.28 & 60 & 0.35 & 0.14 \\
\hline 150 & 0.68 & 0.24 & 90 & 0.37 & 0.13 \\
\hline 180 & 0.63 & 0.19 & 240 & 0.33 & 0.09 \\
\hline
\end{tabular}

Calculations based on activities expressed as $\mathrm{mmol} \mathrm{h}^{-1} \cdot \mathrm{g} \mathrm{VSS}^{-1}$ in experiment 1 and as $\mathrm{mmol} \mathrm{h}^{-1} \mathrm{l}^{-1}$ in experiment 2 . 
These variations of the correlation between $\mathrm{O}_{2}$ consumption and FDA activity could be explained by differences in redox potential between sludges. These differences may also explain why, in our experiments, variations of FDA activity were often closer to those of ETS activity than of $\mathrm{O}_{2}$ consumption, as shown in Table 6 (FDA/ETS ratio more constant than the $0_{2}$ consumption/ETS ratio). ETS activity has been reported $(12,13)$ to measure electron flow rate of respiration either under aerobic or anaerobic conditions (with nitrates as terminal electron acceptor, for example). ETS activity as well as FDA activity thus share the common property to be not closely dependent on sludges $\mathrm{O}_{2}$ concentration.

\section{DISCUSSION}

Results achieved during this study on several experimental pilots and industrial sewage treatment plants show that reproducibility of activity measurements was better with FDA hydrolysis data than with ETS activity data. However FDA hydrolysis involved reactions that may occur at several places along metabolic pathways and either within or outside microbial cells. Achieved values thus only give general indications on metabolic activities in a particular biological reactor. The difficulty to give these results a more precise interpretation, with regard to the lack of precise locations where reactions occur, is partly compensated by the simplicity of the protocol. Fast and inexpensive, this protocol allows large repetitions of measurements. FDA hydrolysis thus appears to be a promising method to promote direct use of microbial activity to monitor and control industrial processes involving biological reactors. Examples of its application are now to be extended to other biological systems, together with further comparisons with the most commonly used alternative methods for biological activity assessment.

From the applications of this method to different sewage treatment plants, it appears that despite the differences in basic mechanisms involved, the informations carried out by FDA hydrolysis and ETS activity on sludge metabolism are generally very similar. As ETS measurement indicates potential activity of bacteria whereas FDA consumption stands for actual hydrolytic activity, these results suggest that ETS-FDA relationships could be valid only in places where microbial activity is high.

Relationships between $\mathrm{O}_{2}$ consumption and FDA hydrolysis appear to be weaker probably because of a smaller dependency of FDA hydrolysis on redox potential. This point is currently being studied in experimental treatment plants together with the correlation between FDA hydrolysis and rates of trophic supply.

\section{REFERENCES}

1. Fontvieille D. et Pattee E., Méthodes de mesure de l'activité globale des biocoénoses. Revue Fr. Sci. Eau, 2, 335-456 (1983).

2. Kenner R.A. and Ahmed S.I., Measurements of electron transport activities in marine phytoplankton. Mar. Biol., 33, 119-127 (1975).

3. Kenner R.A. and Ahmed S.I., A study of in vitro electron transport activity in marine phytoplankton as a function of temperature. J. Phycol., 13, 116-121 (1977).

4. Bamstedt U., ETS activity as an estimator of respiratory rate of zooplankton populations: The significance of variations in environmental factors. J. Exp. Mar. Biol., 42, 267-283 (1950).

5. Medzon E.L. and Bradly M.L., Direct measurement of acetylesterase in living protist cells. J. Bacteriol., 97, $402-415$ (1969).

6. Soderstrom B.E., Vital staining of fungi in pure culture and in soil with fluorescein diacetate. Soil. Biol. Biochem., 9, 59-63 (1977).

7. Swisher R. and Carrol G.C., Fluorescein diacetate hydrolysis as an estimator of microbial biomass on coniferous needle surfaces. Microbial. Ecol., 6, 217-226 (1980).

8. Schnurer J. and Rosswall T., Fluorescein diacetate hydrolysis as a measure of total microbial activity in soil and litter. Appl. Environ. Microbiol., 43, 1256-1261 (1982).

9. Packard T.T., Oxygen consumption in the ocean: measuring and mapping with enzyme analysis. Adv. Chem. Ser., 209, 177-209 (1985).

10. Outaguerouine A., Métrologie de la biomasse en stations d'épuration par mesure d'activité enzymatique. DEA Techniques et Gestion de l'Environnement, Univ. Paris Val de Marne, 77pp (1987). 
11. Packard T.T., Healy M. and Richards F.A., Vertical distribution of the activity of the respiratory electron transport system in marine plankton. Limnol. Oceanog., 16, 60-70 (1971).

12. Tabor P.S. and Neihof R.A., Improved method for determination of respiring individual microorganisms in natural water. Appl. Environment. Microbiol., 43, 1249-1255 (1982).

13. Packard T.T., Garfield P.C. and Martinez R., Respiration and respiration enzyme activity in aerobic and anaerobic cultures of the marine denitrifying bacterium Pseudomonas perfectomarinus. Deep Sea Res., 30, 227-243 (1983). 